\title{
The Investigation of the Relationship between University Students' Levels of Life Quality and Leisure Satisfaction ${ }^{\mathrm{i}}$
}

\author{
Fatih Yaşartürk ${ }^{1}$, Hayri Akyüz ${ }^{1}$, Süleyman Gönülateş ${ }^{2, *}$ \\ ${ }^{1}$ School of Physical Education and Sport, Bartın University, Turkey \\ ${ }^{2}$ Faculty of Sport Sciences, Pamukkale University, Turkey
}

Copyright $\bigcirc 2019$ by authors, all rights reserved. Authors agree that this article remains permanently open access under the terms of the Creative Commons Attribution License 4.0 International License

\begin{abstract}
The purpose of this research is to examine the relationship between university students' levels of life quality and leisure satisfaction according to some demographic variables. 680 (429 men and 251 women) people studying at Bartın University participated in the research. In the research, "Personal Information Form" prepared by researchers, developed by Beard and Ragheb

addition, there was no significant relationship between the participants' mean scores of LSS and QLS $(p>0,05)$. As a result, variables such as family income and personal income were found to have an impact on participants' levels of leisure satisfaction and quality of life, although there was no significant relationship between participants' levels of leisure satisfaction and quality of life.
\end{abstract} (1980) and Turkish adaptation was made by Karlı et al. (2008) "Leisure Satisfaction Scale: LSS" and developed by the World Health Organization and Turkish adaptation was made by Eser et al. (1999) "Quality of Life Scale Short Form: QLS" was used. In the analysis of the data; according to the demographic characteristics of the participants, t-test and ANOVA to investigate the differences between levels of life quality and leisure satisfaction; Pearson Correlation test was applied to examine relations between variables. In the findings of the research, there was no significant difference in the t-test results according to the "gender" variable in the LSS and QLS total score averages ( $>0,05)$. There was no significant relationship between LSS and QLS total score averages according to "age" variables in the correlation test results $(p>0,05)$. There was a significant difference in the "psychological" subscale of the LSS according to the "department" variable in the ANOVA test results $(p<0,05)$. This significant difference is between the physical education and sports teaching and the sport administration department, and it is in favor of the students of the physical education and sports teaching department. In the correlation test results, there was a significant positive and low level relationship between the "family income" variable and the QLS total scores $(p<0,05)$. There was a significant positive and low level relationship between the "personal income" variable and the total scores of LSS and QLS ( $<<0,05)$. On the other hand, there was no significant relationship between the mean scores of LSS and QLS according to the variable "daily leisure time" $(p>0,05)$. In
Keywords University Students, Leisure Satisfaction, Quality of Life

\section{Introduction}

Today, the importance of time is increasing day by day. Because people who use time effectively and efficiently are successful in work, family and school life. Therefore, it is thought that both free time satisfaction and quality of life levels of university students who evaluate time effectively are increased.

The phenomenon of free time is the period spent away the free time allocated to meet the compulsory time and all physiological needs of people defined for work and work life. In addition, this period should include all the activities of the individual's free will. Under these conditions, the term free time can be mentioned [1].

Free time is an important part of our lives. When we participate in satisfying leisure activities, we can gain a sense of freedom, control, creativity and success. Free times also give us the chance to develop our talents, friendships and self-confidence. It helps us to enjoy new experiences, challenges and adventure and to stay healthy [2].

Karaküçük (1991) defined the leisure time as "It is the time of the person for both himself and others to get rid of all imperfections outside of business life, voluntarily and of 
his own will to relax, have fun, or to develop the skills of activities" [3]. In another definition, Dumazedier (1974) defined the free time as $1 \mathrm{t}$ is an activity that outside the necessity of working, the family and the society [4].

Free time satisfaction is the positive satisfaction or emotions that a person presents, achieves and reaches as a result of participation in leisure time activities [5].

Quality of life is considered synonymous with some terms: These can include life satisfaction, self-esteem, well-being, happiness, health, reputation, importance of life, functional status and order $[6,7,8]$.

Based on the literature on quality of life, the existing definitions are made as follows: The concept of quality of life (Quality of life, QOL) defined as the person's perception of his / her position in life related to his / her aims, expectations, standards and interests within the framework of the culture and value systems. It is a broad concept that is influenced in a complex way from the person's physical health, psychological state, beliefs, social relations and the relationship with the environment $[9,22]$. In another definition, quality of life is a concept that shows the personal reactions to the illnesses and the daily physical, mental and social effects that affect the level of personal satisfaction that can be achieved in living conditions. It contains culture, value judgments, person's position and objectives [10]. One of the reasons that decreases the quality of life is the increasing health problems and health status variables. However, there are many reasons affecting the quality of life. We can group these reasons as follows;

- Individual Variables: Gender, age and some inherited characteristics.

- Social Variables: These are the variables that show the social support of society.

- Economic Variables: It is the income and the continuity of the income that will provide a livelihood for the person to live in humanitarian conditions during retirement.

- Psychological Variables: It is one of the variables of general happiness and satisfaction of the person.

- Health Status Variables:

- Environmental Variables: Regulating the physical environment in which the person lives, improving the mobility and health of the person positively affects the quality of life $[20,23]$.

The aim of this study is to examine the relationship between the free time satisfaction of university students and quality of life according to some demographic variables.

\section{Materials and Methods}

In accordance with the research objectives, "Descriptive and Relational Screening Model" was used.

\subsection{Research Group}

The sample group consisted of 680 (429 male and 251 female) participants selected by simple random sampling method.

\subsection{Data Collection Tools}

Personal Information Form: Personal information form consists of variables such as gender, age, department, family income, personal income and free time period.

Leisure Satisfaction Scale: Leisure Satisfaction Scale (LSS) which The Turkish version was developed by Beard and Ragheb (1980), and the Turkish version of Karlı et al. (2008), and which consist of 51 expressions and six sub-dimensions (psychological, education, social, relaxation, physiological and aesthetic) was used $[5,11]$.

The 5-point Likert type scale was used to evaluate the expressions in the scale $(1=$ is almost never available for me, 2 = this is rarely available for me, $3=$ is Sometimes available for me, $4=$ Frequently available for me, $5=$ Almost always available for me). The Cronbach Alpha coefficients of the sub-dimensions ranged from ,79 to ,84 whereas the Cronbach Alpha coefficient of the total scale was, 92 .

Quality of Life Scale: The World Health Organization Quality of Life Scale (QLS) Short Form (WHOQOL-BREF-TR) is a form developed by World Health Organization. The aim is to measure the person's well-being and to make cross-cultural comparisons [12]. It is a short form of the WHOQOL-100 scale consisting of 100 questions. One question was taken from WHOQOL-100 for each of the 24 chapters; two questions related to general health and quality of life were added. One more question was added for adapting to the Turkish Community. The question 27 is the national question. The validity and reliability studies of the scale were performed by Eser and others in 1999. It enables to question the quality of life in 4 different factors. Factors were separated from each other by considering the quality of life. These factors;

- $\quad 1^{\text {st }}$ Factor: Physical health

- $\quad 2^{\text {nd }}$ Factor: Psychological health

- $\quad 3^{\text {rd }}$ Factor: Social relations

- $4^{\text {th }}$ Factor: It is the area of environmental health.

Field scores are calculated between 4-20. As points increase, the Quality of life also increases [12, 13].

\subsection{Data Analysis}

In the analysis of the data, t-Test and ANOVA were applied to examine the differences between the quality of life and free time satisfaction according to the demographic characteristics of the participants; Pearson Correlation test was used to investigate the relationships between the variables. 


\section{Findings}

Table 1. Frequency and Percent Values of Participants by Demographic Variables

\begin{tabular}{lccc}
\hline Variables & & $\mathbf{N}$ & $\mathbf{\%}$ \\
\hline \multirow{2}{*}{ Gender } & Female & 251 & 36,9 \\
& Male & 429 & 63,1 \\
\cline { 2 - 4 } & Physical Education and Sports Teaching & 156 & 22,9 \\
\cline { 2 - 4 } Department & Coaching Training & 243 & 35,7 \\
& Sports Management & 89 & 13,2 \\
\cline { 2 - 5 } & Recreation & 192 & 28,2 \\
\hline
\end{tabular}

According the table, 36,9\% of the participants are female and 63,1\% are male. $22,9 \%$ of the sample group were Physical Education and Sports Teaching, 35,7\% were Coaching Training, 13,2\% were Sports Management and 28,2\% were studying in the Recreation Department.

Table 2. Mean Results of Participants by Demographic Variables

\begin{tabular}{lccc}
\hline Variables & $\mathbf{N}$ & $\bar{x}$ & $\mathbf{S}$ \\
\hline Age & 680 & 21,62 & 2,45 \\
\hline Family Income & 680 & 2440,58 & 1179,72 \\
\hline Personal Income & 680 & 745,87 & 317,47 \\
\hline Daily Free Time Duration & 680 & 4,8 & 3,11 \\
\hline
\end{tabular}

The mean age of the participants was 21,62; family income average is $2440,58 \mathrm{TL}$; their personal income average is $745,87 \mathrm{TL}$ and the free time period is 4,8 hours.

Table 3. Independent Two Sample t-Test Results for Gender Variables

\begin{tabular}{|c|c|c|c|c|c|c|c|}
\hline Scales & Gender & $\mathbf{N}$ & $x$ & SS & $\mathbf{t}$ & sd & $\mathbf{p}$ \\
\hline \multirow{2}{*}{ General health } & Female & 251 & 3,48 &, 755 & \multirow{2}{*}{,- 755} & \multirow{2}{*}{678} & \multirow[t]{2}{*}{,652 } \\
\hline & Male & 429 & 3,53 &, 826 & & & \\
\hline \multirow{2}{*}{ Physical } & Female & 251 & 3,50 &, 588 & \multirow[t]{2}{*}{, 810} & \multirow{2}{*}{678} & \multirow[t]{2}{*}{,748 } \\
\hline & Male & 429 & 3,46 & ,603 & & & \\
\hline \multirow{2}{*}{ Psychological } & Female & 251 & 3,44 & ,620 & \multirow[t]{2}{*}{, 125} & \multirow{2}{*}{678} & \multirow[t]{2}{*}{, 587} \\
\hline & Male & 429 & 3,43 & ,613 & & & \\
\hline \multirow{2}{*}{ Environmental } & Female & 251 & 3,35 & ,603 & \multirow[t]{2}{*}{,297 } & \multirow{2}{*}{678} & \multirow[t]{2}{*}{,369 } \\
\hline & Male & 429 & 3,34 &, 580 & & & \\
\hline \multirow{2}{*}{ Social Relations } & Female & 251 & 3,44 &, 810 & \multirow[t]{2}{*}{,278 } & \multirow{2}{*}{678} & \multirow[t]{2}{*}{,258 } \\
\hline & Male & 429 & 3,42 & ,802 & & & \\
\hline \multirow{2}{*}{ QLS } & Female & 251 & 3,43 &, 524 & \multirow{2}{*}{,371 } & \multirow{2}{*}{678} & \multirow{2}{*}{,478 } \\
\hline & Male & 429 & 3,41 & ,532 & & & \\
\hline \multirow{2}{*}{ Psychological } & Female & 251 & 3,56 & ,789 & \multirow{2}{*}{,- 948} & \multirow{2}{*}{678} & \multirow{2}{*}{, 540} \\
\hline & Male & 429 & 3,62 & ,785 & & & \\
\hline \multirow{2}{*}{ Education } & Female & 251 & 3,60 &, 835 & \multirow{2}{*}{,- 924} & \multirow{2}{*}{678} & \multirow{2}{*}{,225 } \\
\hline & Male & 429 & 3,66 & ,798 & & & \\
\hline Social & Female & 251 & 3,62 &, 775 & -1142 & 678 & 382 \\
\hline Soctar & Male & 429 & 3,69 &, 737 & $-1,142$ & $0 / 0$ & (20) \\
\hline Plaxation & Female & 251 & 3,69 & ,940 & 1174 & 678 & 260 \\
\hline Ketaxation & Male & 429 & 3,78 & ,911 & $-1,1 / 4$ & 010 &, 209 \\
\hline Phyciological & Female & 251 & 3,49 &, 783 & 1315 & 678 & $881>-1$ \\
\hline 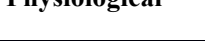 & Male & 429 & 3,58 & ,789 & $-1,315$ & $0 / 8$ & 1881 \\
\hline Aesthetic & Female & 251 & 3,62 & ,866 & -453 & 678 & 508 \\
\hline Aestivetic & Male & 429 & 3,65 & ,892 & - & $0 / 0$ & , \\
\hline $\mathbf{I S C}$ & Female & 251 & 3,59 & ,701 & 1161 & 678 & 727 \\
\hline Hov & Male & 429 & 3,65 & 699, & $-1,101$ & 070 &, 122 \\
\hline
\end{tabular}


There were no statistically significant differences between the mean scores and subscales of the participants and the mean scores and subscales of the participants according to the table in terms of gender variable $(p>0,05)$.

Table 4. QLS and LSS Correlation Test Results by Age Variables

\begin{tabular}{cccccccc}
\hline Variable & General Health & Physical & Psychological & Environmental & Social Relations & QLS & \\
\hline Age &,- 058 &, 089 &, 057 &, 058 &, 068 &, 098 & Aesthetic \\
\hline & Psychological & Education & Social & Relaxation & Physiological & LS \\
\hline Age &, 036 &, 071 &, 025 &, 022 &, 017 &, 004 &, 039 \\
\hline
\end{tabular}

According to the table, no significant relationship was found as a result of correlation analysis to show the relationship between age variable and QLS score averages and sub-dimensions, LSS score averages and sub-dimensions ( $>00,05)$.

Table 5. QLS and LSS ANOVA Test Results According to Department Variable of Participants

\begin{tabular}{|c|c|c|c|c|c|c|c|}
\hline Scales & $\begin{array}{l}\text { Source of } \\
\text { Variance }\end{array}$ & $\begin{array}{c}\text { Sum of } \\
\text { Squares }\end{array}$ & sd & $\begin{array}{c}\text { Square } \\
\text { Average }\end{array}$ & $\mathbf{F}$ & $\mathbf{p}$ & Significant Dif. \\
\hline \multirow[t]{2}{*}{ General Health } & Between Groups & 3,76 & 3 &, 878 & \multirow{2}{*}{1,478} & \multirow{2}{*}{,269 } & \\
\hline & In groups & 411,94 & 677 & ,588 & & & \\
\hline \multirow[t]{2}{*}{ Physical } & Between Groups &, 26 & 3 & , 147 & \multirow{2}{*}{, 254} & \multirow{2}{*}{, 844} & \\
\hline & In groups & 256,82 & 677 & ,298 & & & \\
\hline \multirow[t]{2}{*}{ Psychological } & Between Groups &, 95 & 3 &, 257 & \multirow{2}{*}{,478 } & \multirow{2}{*}{, 566} & \\
\hline & In groups & 254,48 & 677 &, 357 & & & \\
\hline \multirow[t]{2}{*}{ Environmental } & Between Groups &, 35 & 3 &, 157 & \multirow{2}{*}{,368 } & \multirow{2}{*}{, 774} & \\
\hline & In groups & 213,19 & 677 & ,258 & & & \\
\hline \multirow{2}{*}{ Social Relations } & Between Groups & 1,62 & 3 &, 578 & \multirow{2}{*}{, 877} & \multirow{2}{*}{, 458} & \\
\hline & In groups & 444,47 & 677 & ,698 & & & \\
\hline \multirow[t]{2}{*}{ QLS } & Between Groups &, 48 & 3 &, 147 & \multirow{2}{*}{, 555} & \multirow{2}{*}{,658 } & \\
\hline & In groups & 187,47 & 677 &, 257 & & & \\
\hline \multirow{2}{*}{ Psychological } & Between Groups & 5,12 & 3 & 1,707 & \multirow{2}{*}{2,779} & \multirow{2}{*}{, 040} & \multirow{2}{*}{$1>3$} \\
\hline & In groups & 431,31 & 677 & ,614 & & & \\
\hline \multirow{2}{*}{ Education } & Between Groups & 4,04 & 3 & 1,349 & \multirow{2}{*}{2,062} & \multirow{2}{*}{,104 } & \\
\hline & In groups & 459,47 & 677 & ,655 & & & \\
\hline \multirow{2}{*}{ Social } & Between Groups & 1,79 & 3 &, 598 & \multirow{2}{*}{1,061} & \multirow{2}{*}{,365 } & \\
\hline & In groups & 395,83 & 677 &, 564 & & & \\
\hline \multirow{2}{*}{ Relaxation } & Between Groups & 4,27 & 3 & 1,426 & \multirow{2}{*}{1,683} & \multirow{2}{*}{, 169} & \\
\hline & In groups & 594,70 & 677 &, 847 & & & \\
\hline \multirow{2}{*}{ Physiological } & Between Groups & 1,96 & 3 & ,655 & 1055 & 360 & \\
\hline & In groups & 435,87 & 677 & ,621 & $1,0 J 3$ & - 500 & \\
\hline t s th & Between Groups & 4,18 & 3 & 1,393 & 1707 & 117 & \\
\hline Aestmetic & In groups & 545,89 & 677 & ,778 & $1, \sqrt{92}$ & , 14/ & \\
\hline $\mathrm{ISC}$ & Between Groups & 3,13 & 3 & 1,046 & 0142 & 004 & \\
\hline LSS & In groups & 342,81 & 677 & ,488 & 2,143 & - & \\
\hline
\end{tabular}

Department Groups: 1=Physical Education and Sports Teaching, 2=Coaching Training, 3= Sports Management, 4=Recreation

According to the table, a statistically significant relationship was found in the psychological sub-dimension of the LSS with the section variable $(\mathrm{p}<0,05)$. This meaningful difference according to the department variable is among the departments of sports management and physical education and sports teaching, and is in favor of the students of physical education and sports education department. 
Table 6. QLS and LSS Correlation Test Results by Family Income Variables

\begin{tabular}{cccccccc}
\hline Variable & General Health & Physical & Psychological & Environmental & Social Relations & QLS \\
\hline $\begin{array}{l}\text { Family } \\
\text { Income }\end{array}$ &, 065 &, 098 &, 074 &, $014^{*}$ &, 058 &, $011^{*}$ & Aesthetic \\
\hline & Psychological & Education & Social & Relaxation & Physiological &, 019 &, 031 \\
\hline $\begin{array}{l}\text { Family } \\
\text { Income }\end{array}$ &, 055 &, 012 &, 020 &, 043 &, 013 & \multirow{2}{*}{ L }
\end{tabular}

$* \mathrm{p}<0,05$

According to the table, as a result of the correlation analysis performed to show the relationship between the family income variable and the QLS score averages and sub-dimensions, LSS averages and sub-dimensions; A statistically significant low positive correlation was found in the mean QLS $\left(\mathrm{r}=, 0148^{*}, \mathrm{p}<0,05\right)$ sub-dimension and total score of AQI $\left(\mathrm{r}=, 111^{*}, \mathrm{p}<0,05\right)$.

Table 7. QLS and LSS Correlation Test Results According to Personal Income Variables

\begin{tabular}{|c|c|c|c|c|c|c|c|}
\hline Variable & General Health & Physical & Psychological & Environmental & Social Relations & QLS & \\
\hline \multirow[t]{2}{*}{$\begin{array}{c}\text { Personal } \\
\text { Income }\end{array}$} &, $077^{*}$ &, $089^{*}$ &, $152^{*}$ &, $189^{*}$ &, $172^{*}$ &, $189^{*}$ & \\
\hline & Psychological & Education & Social & Relaxation & Physiological & Aesthetic & LSS \\
\hline $\begin{array}{l}\text { Personal } \\
\text { Income }\end{array}$ &, $126^{*}$ &, $118^{*}$ &, $111^{*}$ &, $117^{*}$ &, $077^{*}$ &, $120^{*}$ &, $129^{*}$ \\
\hline
\end{tabular}

$* \mathrm{p}<0,05$

According to the table, as a result of the correlation analysis performed to show the relationship between personal income variable and QLS score averages and sub-dimensions, LSS averages and sub-dimensions; There was a statistically significant low positive correlation between QLS score averages and sub-dimensions, LSS mean scores and sub-dimensions $(\mathrm{p}<0,05)$.

Table 8. QLS and LSS Correlation Test Results by Free Time Period Variables of Participants

\begin{tabular}{|c|c|c|c|c|c|c|c|}
\hline Variable & General Health & Physical & Psychological & Environmental & Social Relations & QLS & \\
\hline $\begin{array}{l}\text { Free Time } \\
\text { Duration }\end{array}$ &,- 087 & ,032 &,- 036 &, 014 &, 014 &,- 078 & \\
\hline & Psychological & Education & Social & Relaxation & Physiological & Aesthetic & LSS \\
\hline $\begin{array}{c}\text { Free Time } \\
\text { Duration }\end{array}$ &, 031 &,- 011 & 001 &,- 030 &,- 015 &, 015 &,- 001 \\
\hline
\end{tabular}

$* \mathrm{p}<0,05$

According to the table, there was no significant relationship between the free time duration variable and QLS mean scores and sub-dimensions, LSS score averages and sub-dimensions $(\mathrm{p}>0,05)$.

Table 9. QLS and LSS Correlation Test Results of the Participants

\begin{tabular}{lll}
\hline & & LSS \\
\hline QLS & $\mathrm{r}$ &,- 051 \\
\hline $\mathrm{*}<0,05$ & &
\end{tabular}

According to the table, no significant relationship was found as a result of the correlation analysis to show the relationship between the mean score of QLS and LSS scores averages $(p>0,05)$. 


\section{Discussion and Conclusions}

According to the gender variable, there was no statistically significant difference between the QLS mean scores and subscales; and the mean scores and subscales of the LSS of the participants ( $p>0.05$ ). Yildirım et al. (2004) found that there is no difference in the quality of life among people with physical health problems. Yildırım et al. (2004) 's result is in parallel with our study [14]. The study of Vong Tze (2005) on people living in various countries has found a significant difference in free time satisfaction according to the gender variable [15]. However, as in many studies, Ardahan and Yerlisu (2010) and Hintikka et al (2001) emphasized that the free time satisfaction level of university students did not differ according to the gender variable $[16,21]$. Similar results were found in the study of $\mathrm{Lu}$ and $\mathrm{Hu}$ (2005) on Chinese students [17]. We can say that the gender variable does not lead to a difference in satisfaction levels of university students for leisure time activities.

According to the age variable, there was no significant relationship between the participants' QLS score averages and sub-dimensions, LSS score averages and sub-dimensions ( $p>0,05)$. Akal (2005) found in their master thesis that the differences between individuals' ages and quality of life scores were significantly different and the quality of life scores decreased significantly with the increase in age [18]. Since the sample group in our study is university students, the average age is close to each other and called as young. Therefore, we can say that there is no significant relationship between the quality of life of university students and the average age of " 21,62 ".

While no significant difference was found between QLS score averages and sub-dimensions according to department variable, there was a statistically significant difference in LSS at the psychological" sub-dimension $(p<0,05)$. According to the department variable, this meaningful difference is found among the departments of physical education and sports teaching and sports management, and it is concluded that it is in favor of physical education and sports teaching students. When the general average of the students who have entered the department by ÖSYM and the Special Ability Examination is examined, the students who have gained physical education and sports teaching department have achieved success with higher score and special ability. Therefore, according to our findings, the students who are successful are expected to reflect their quality of life positively.

According to family income variable; As a result of the correlation analysis performed to show the relationship between the mean scores and the sub-dimensions of QLS and LSS scores and sub-dimensions; a statistically significant low positive correlation was found in the total subscale scores of the QLS and the total score of the QLS. According to the personal income variable, in the correlation analysis performed to show the relationship between the mean scores and the sub-dimensions of QLS and LSS scores and sub-dimensions; There was a statistically significant low positive correlation between QLS score averages and sub-dimensions, LSS mean scores and sub-dimensions $(p<0,05)$. As the family income of university students increases, there will be a variety of free time activities and these activities will affect life satisfaction positively. Also, as the increase in "family and personal" income level facilitates living conditions, It is foreseeable that the level of satisfaction in both environmental and leisure activities will increase. In their study, Abobului et al. (2015) found that people with high income perception had a higher quality of life and were positively affected by their activities [19].

According to the free time duration variable, As a result of the correlation analysis performed to show the relationship between "mean score and sub-dimensions of QLS, mean scores and sub-dimensions of LSS", no significant relationship was found $(p>0,05)$. No significant relationship was found as a result of the correlation analysis to show the relationship between the mean scores of QLS and LSS mean scores $(p>0,05)$. We can say that university students have an impact on this result because they cannot cause enough time in free time.

Although there was no significant relationship between free time satisfaction and quality of life levels of university students, it was found that variables such as family income and personal income had an effect on free time satisfaction and quality of life of the participants. According to this result, quality of life and free time satisfaction levels of university students vary according to individual differences; and that the increase in income levels have a positive effect on satisfaction and satisfaction levels.

\section{REFERENCES}

[1] Yayl1, A. (2014). Rekreasyona giriş (2nd Edition). Ankara: Detay Yayıncilik. (Turkish)

[2] Torkildsen, G. (1999). Leisure and recreation management. London, UK: Spon Pres.

[3] Karaküçük, S. (2005). Rekreasyon boş zamanları değerlendirme (5th Edition). Ankara: Gazi Kitapevi. (Turkish)

[4] Dumazedier, J. (1974). Leisure and the social system. In J. F. Murphy (Ed.) Concepts of Leisure, Englewood Cliffs, NJ, Prentice-Hall, 133

[5] Beard, J.G., \& Ragheb, M.G. (1980). Measuring leisure satisfaction. Journal of Leisure. Research, 12(1), 20-33. DOI: $10.1080 / 00222216.1980 .11969416$

[6] Zorba, E. (2006). Yaşam boyu spor (2nd Edition). Ankara: Nobel Yayın Dağıtım. (Turkish) 
[7] İpekoğlu, G., Sever, O., Gönülateş, S., Bayrakdar, A., Arslanoğlu, E., Arslanoğlu, C., \& Çolakoğlu, F. F. (2017). Does chronic smoking affect induced-exercise catecholamine release?. International Journal of Applied Exercise Physiology, 6(1), 16-20. DOI: 10.22631/ijaep.v6i1.122

[8] Kırgız, C., Şenel, Ö., Arslanoğlu, E., \& Sever, O. (2014). Investigation of quality of life of teaching staffs in physical education and sport department. e-Kafkas Ĕ̈itim Araştırmaları Dergisi, 1(2), 1-6. Retrieved from http://dergipark.gov.tr/kafkasegt/issue/19193/204080

[9] World Health Organization. (1997). The world health organization quality of life instruments (The whoqol-100 and the whoqol-bref). Whoqol Measuring Quality of Life, Programme on Mental Health Division of Mental Health and Prevention of Substance Abuse.

[10] Avc1, K., \& Pala, K. (2004). Evaluation of the quality of life of research assistants and specialists working in uludag university school of medicine. Uludağ University Journal of Medical Faculty, 30(2), 81-85. Retrieved from http://dergipark.gov.tr/uutfd/issue/35311/391969

[11] Karlı, Ü., Polat, E., Yılmaz, B., \& Koçak, S. (2008). Reliability and validity study of leisure satisfaction scale (lss-long version). Hacettepe Journal of Sport Sciences, 19(2), 80-91. Retrieved from http://dergipark.gov.tr/sbd/iss ue/16393/171423

[12] Eser, E., Fidaner, H., Fidaner, C., Eser, S.Y., Elbi, H., \& Göker, E. (1999). WHOQOL-100 and WHOQOL-BREF's psychometric characteristics. Journal of 3P, 7(2), 23-40.

[13] Oliver, M. (1997). WHOQOL-Bref. University of Washington Seattle, United States of America, United States Version, 1-38.

[14] Taşkaya, S. (2014). Diyabet hastalarının tedaviye uyum düzeyleri ile sağglı hizmeti kullanımı ve yaşam kalitesini etkileyen faktörler. PHD Thesis. Hacettepe University, Institute of Health Sciences, Ankara.

[15] Vong, Tze, N. (2005). Leisure satisfaction and quality of life in Macao, China. Leisure Studies, 24(2), 195-207. DOI: 10.1007/s10902-005-8628-3

[16] Ardahan, F., \& Yerlisu Lapa, T. (2010). Üniversite öğrencilerinin serbest zaman tatmin düzeylerinin cinsiyete ve gelire göre incelenmesi. Hacettep Journal of Sport Sciences, 21(4), 129-136. Retrieved from http://dergipark.gov.tr/sbd/issue/16387/171397

[17] Lu, L., \& Hu, C.H. (2005). Personality, leisure experiences and happiness. Journal of Happiness Studies, 6(3), 325-342. DOI: $10.1007 / \mathrm{s} 10902-005-8628-3$

[18] Değirmenci Akal D. (2005). Evaluation of Factors affecting the quality of life of elderly people living at home, Master Thesis. Cumhuriyet University, Institute of Health Sciences, Sivas.

[19] Abobului, M., Berghea, F., Vlad, V., Balanescu, A., Opris, D., Bojinca, V., \& Predeteanu, D. and Ionescu, R. (2015). Socio-economical factors that influence the perception of quality of life in patients with osteoporosis. Journal of Medicine and Life, 8(Special Issue), 109-114.

[20] Keskinoğlu., P, Bilgiç, N., Pıçakçıefe, M., \& Uçku, R.
(2003). The prevalence of the chronic disease and disability in elderly population at çamdibi- 1 health center's region in İzmir. Turkish Journal of Geriatrics, 6(1), 27-30.

[21] Hintikka, J., Koskela, T., Kontula, O., Koskela, J., Koivumaa-Honkanen, T., \& Viinamäki, H. (2001). Religious attendance and life satisfaction in the finnish general population. Journal of Psychology and Theology, 29(2), 158-164. DOI: 10.1177/009164710102900207

[22] O'Carroll, R. E., Smith, K., Couston, M., Cossar, J. A., \& Hayes, P. C. (200). A comparison of the WHOQOL-100 and the WHOQOL-BREF in detecting change in quality of life following liver transplantation. Quality of Life Research, 9(1), 121-124. DOI: 10.1023/A:1008901320492

[23] Özerdoğan, Ö., Yüksel, B., Çelik, M., Oymak, S., \& Bakar, Ç. (2018). Associated factors affecting the quality of life of the elderly. Turk Journal of Public Health, 16(2), 90-105. DOI: 10.20518/tjph.458209

i This study was presented as a special paper at the First International Sports and Wellness Congress for All. 